\title{
2-(Aminomethyl)benzimidazole/ $\mathrm{Cu}^{2+}$ immobilized on $\mathrm{Fe}_{3} \mathrm{O}_{4} @ \mathrm{SiO}_{2}$ : a convenient magnetic nanocatalyst for click reaction of aryl iodide/benzyl halide, sodium azide and terminal alkyne
}

\author{
Mostafa Mehdipour a and Mohammad Reza Khodabakhshi ${ }^{a^{*}}$
}

a Applied Biotechnology Research Center, Baqiyatallah University of Medical Sciences, Vanak Square, Mollasadra Ave. P.O. Box: 1435915371, Tehran, Iran

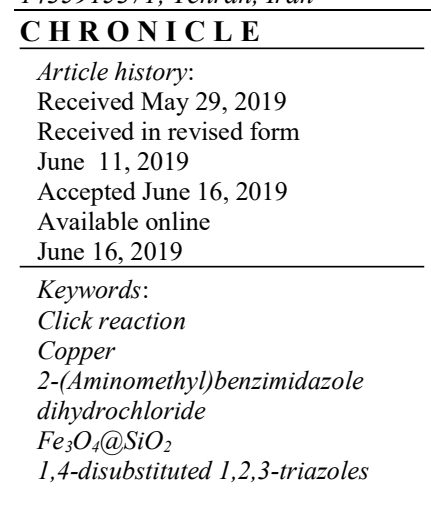

\begin{abstract}
A B S T R A C T
In this work, the $\mathrm{Fe}_{3} \mathrm{O}_{4} @ \mathrm{SiO}_{2} @ \mathrm{AMBI} / \mathrm{Cu}$ nanocatalyst was synthesized and used as a wellorganized magnetic nanocatalyst for the click reaction. This nanocatalyst has effectively catalyzed the cyclization of terminal alkynes and sodium azide with aryl iodide/benzyl halide for the formation of 1,4-disubstituted 1,2,3-triazoles under mild reaction conditions with good to high yields in low reaction time.
\end{abstract}

\section{Introduction}

The term bioorthogonal chemistry was born in 2003 by Bertozzi ${ }^{1}$. Bioorthogonal chemistry is about designing reactions that can be achieved in a biological environment and proceeded in living systems. This kind of reactions are posing great biocompatibility and selectivity, also opening new approaches for new innovations in biology by feasible various bond formations in biological systems. From this kind of reactions, click reaction should be mentioned. This reaction was defined in 2001 by Sharpless as an insensitive and easy performing reaction by accessible reagents. ${ }^{2-3}$ In this reaction, triazoles can be synthesized by the reaction of azide and terminal amide and in the presence of $\mathrm{Cu}$ as the catalyst. Click chemistry is one of the newest and most operative tools for the synthesis of drug-like heterocyclic compounds with carbon-heteroatom-carbon $(\mathrm{C}-\mathrm{X}-\mathrm{C})$ bonds that can accelerate the drug discovery improvement and lead to synthesis of biological compounds with anti-HIV, antiviral, antibiotic and antibacterial activities. ${ }^{4-10}$ Until today, many articles have reported click chemistry by various $\mathrm{Cu}-$ catalyzed procedures, but due to its importance, it is necessary to develop new methodologies.

\footnotetext{
* Corresponding author.

E-mail address: khodabakhshi2002@gmail.com (M. R. Khodabakhshi)

(C) 2020 by the authors; licensee Growing Science, Canada
}

doi: $10.5267 /$ j.ccl.2019.006.004 
History of using metal catalysis for heterogeneous catalysis is going back to 60 years ago. ${ }^{11-13}$ In heterogeneous catalysis, phase of the catalyst, reactant, and product are different. Thus, the catalyst can be separated from the reaction media more easily compared to homogeneous catalysis. Using transition metals in heterogeneous catalysis, due to their properties, is becoming more and more common during time. Among transition metals, $\mathrm{Cu}$, as an economic and environmentally fried metal, could be a reliable choice for synthesizing an efficient catalyst. Some of the reported applications of $\mathrm{Cu}$ are as followed: selective $\mathrm{CO}$ bond cleavage of glycerol ${ }^{14}$, reduction of $\mathrm{CO}_{2}$ electrochemically, ${ }^{15}$ catalytic dehydrogenation, catalytic $\mathrm{NO}$ reduction ${ }^{16}$, and $\mathrm{CH}$ activation.${ }^{17}$

In metal catalysis, among various variables that affect the catalytic behavior of the catalyst, the size of the particles, the shape of the particles, the nature of the selected support for immobilizing metal particles on it, and also the nature of other metals present in the structure of the catalyst could be named. According to the influence of the size in the efficiency of the catalyst, synthesizing nanoparticles could be highly beneficial due to their high surface area. As a result, among this explosion of research in the field of nanocatalysis for various reactions such as reduction, oxidation, hydrogenation, electrocatalytic, organic reactions, and photocatalytic reaction, synthesizing metal nanocatalysts with promised properties is even a huge challenge. ${ }^{18}$

Herein, to improve previous researches and to prepare effective heterogeneous catalysts to proceed click reaction, the $\mathrm{Fe}_{3} \mathrm{O}_{4} @ \mathrm{SiO}_{2} @ \mathrm{AMBI} / \mathrm{Cu}$ nanocatalyst was synthesized using $\mathrm{FeCl}_{3} \cdot 6 \mathrm{H}_{2} \mathrm{O}$, $\mathrm{FeCl}_{2} .4 \mathrm{H}_{2} \mathrm{O}$, NH $\mathrm{NH}_{4} \mathrm{OH}$, tetraethyl orthosilicate (TEOS), 2-(aminomethyl) benzimidazole dihydrochloride (AMBI), and $\mathrm{Cu}(\mathrm{OAc})_{2}$, and used as an efficient magnetic nanocatalyst (Scheme 1). This nanocatalyst has effectively catalyzed the synthesis of 1,4-disubstituted-1,2,3-triazoles using terminal aryl alkynes, sodium azide and aryl iodide/benzyl halide with good to high yields in low reaction time (Scheme 1). The most challenging subject of this procedure was the performing of the coupling reaction using $\mathrm{Cu}$-catalyst. This process was carried out successfully in the presence of Lproline with quiet satisfactory results.
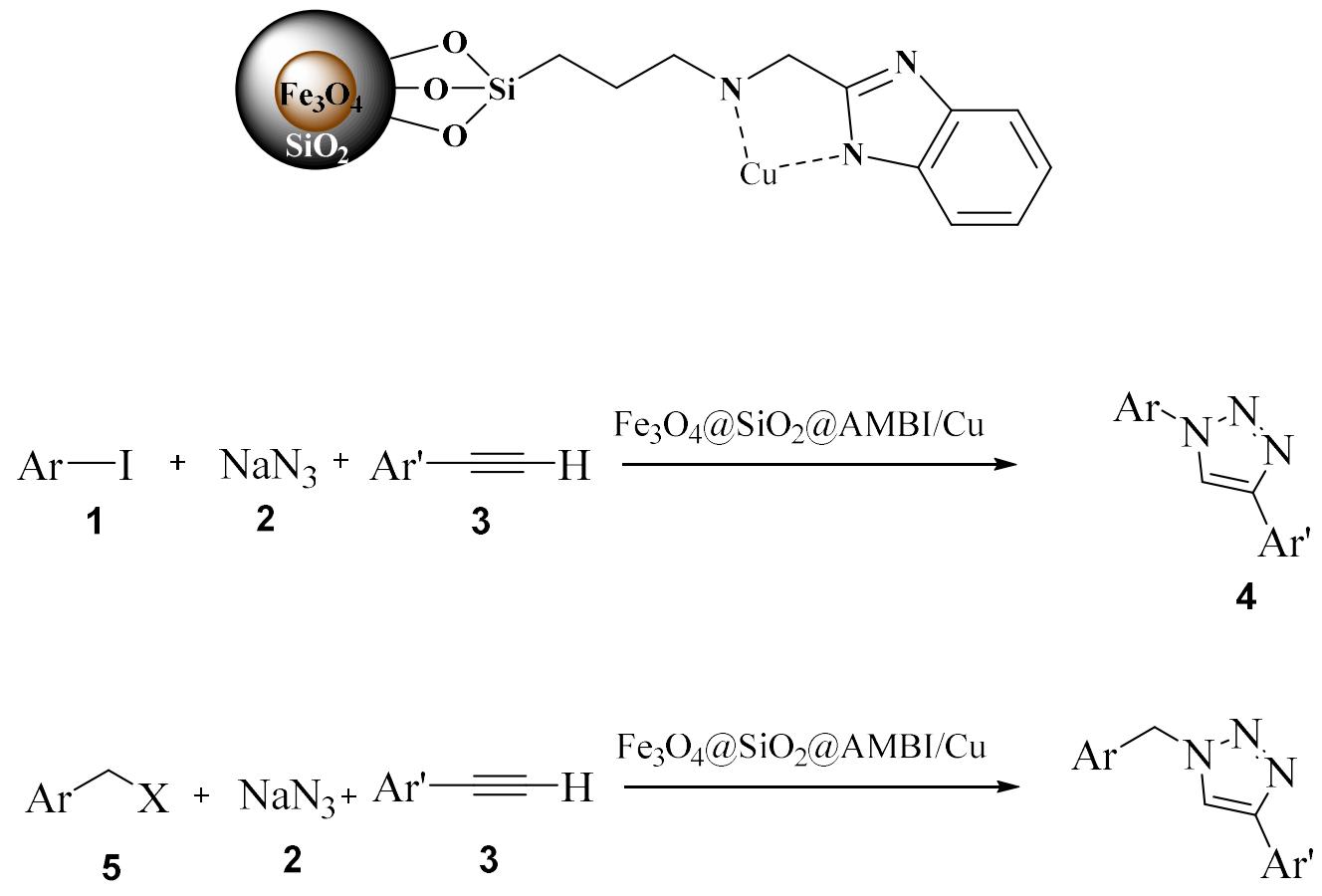

Scheme 1. Click reactions using $\mathrm{Fe}_{3} \mathrm{O}_{4} @ \mathrm{SiO}_{2} @ \mathrm{AMBI} / \mathrm{Cu}$ nanocatalyst 


\section{Results and Discussion}

FT-IR spectra of $\mathrm{Fe}_{3} \mathrm{O}_{4}, \mathrm{Fe}_{3} \mathrm{O}_{4} @ \mathrm{SiO}_{2}$, and $\mathrm{Fe}_{3} \mathrm{O}_{4} @ \mathrm{SiO}_{2} @ \mathrm{AMBI} / \mathrm{Cu}$ are illustrated in Figure 1. As illustrated in Figure 1, functional groups of $\mathrm{Fe}_{3} \mathrm{O}_{4}, \mathrm{Fe}_{3} \mathrm{O}_{4} @ \mathrm{SiO}_{2}$, and $\mathrm{Fe}_{3} \mathrm{O}_{4} @ \mathrm{SiO}_{2} @ \mathrm{AMBI} / \mathrm{Cu}$ can be seen in FT-IR spectra. In the FT-IR spectra of $\mathrm{Fe}_{3} \mathrm{O}_{4}$, a broad peak at around $500-600 \mathrm{~cm}^{-1}$ is attributed to the Fe-O group. In $\mathrm{Fe}_{3} \mathrm{O}_{4} @ \mathrm{SiO}_{2}$ spectra, in addition to the Fe-O peak, a broad peak at 1050-1250 $\mathrm{cm}^{-1}$ is related to the presence of the Si-O group. Also, in the $\mathrm{Fe}_{3} \mathrm{O}_{4} @ \mathrm{SiO}_{2} @ \mathrm{AMBI} / \mathrm{Cu}$ spectra, in addition to all of the abovementioned peaks, a $\mathrm{C}=\mathrm{C}$ stretching peak and a characterization peak of $\mathrm{N}$ $\mathrm{H}$ are observed at $1649 \mathrm{~cm}^{-1}$ and $3400 \mathrm{~cm}^{-1}$, respectively.

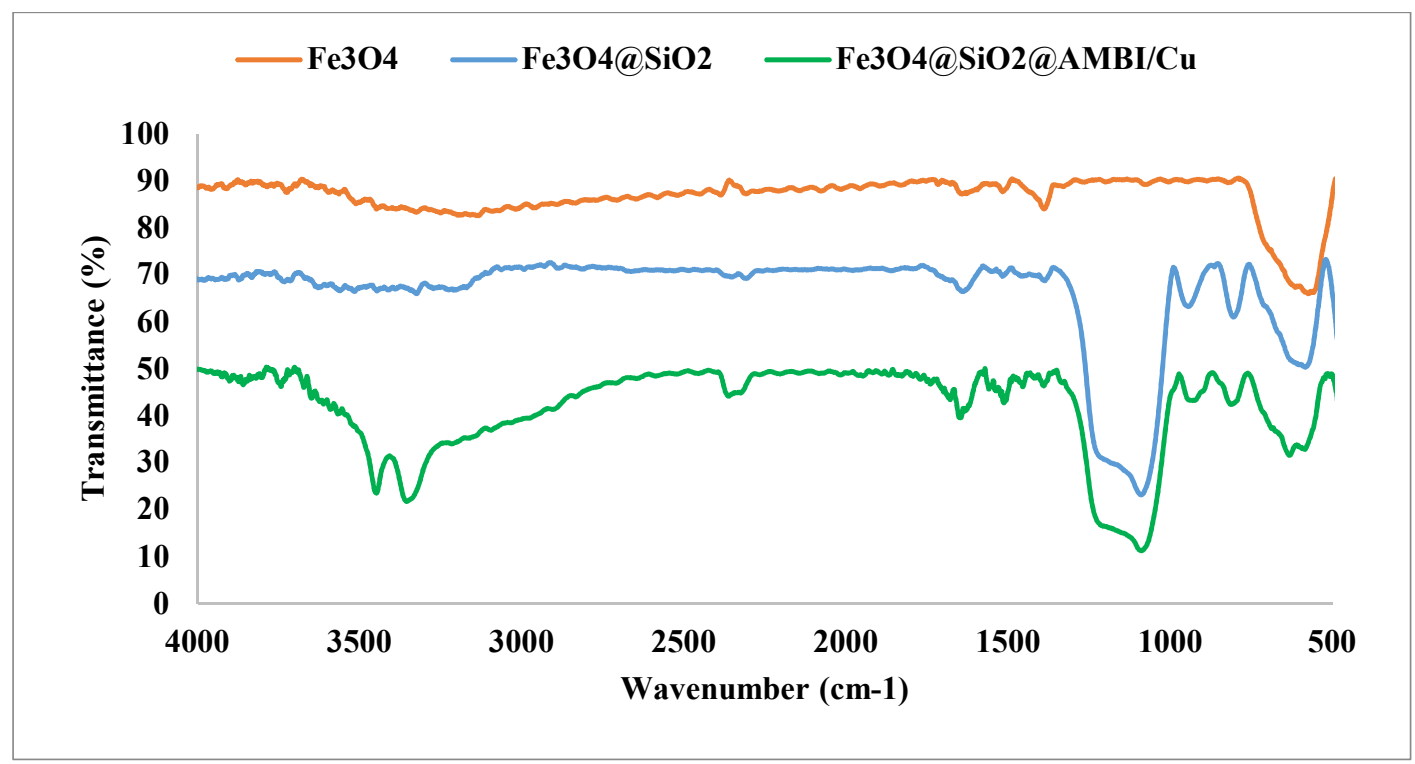

Fig. 1. FT-IR spectra of a) $\mathrm{Fe}_{3} \mathrm{O}_{4}$, b) $\mathrm{Fe}_{3} \mathrm{O}_{4} @ \mathrm{SiO}_{2}$, and c) $\mathrm{Fe}_{3} \mathrm{O}_{4} @ \mathrm{SiO}_{2} @ \mathrm{AMBI} / \mathrm{Cu}$

The morphology and size of synthesized $\mathrm{Fe}_{3} \mathrm{O}_{4} @ \mathrm{SiO}_{2} @ \mathrm{AMBI} / \mathrm{Cu}$ were studied by SEM and TEM images and they are shown in Figure 2. Consequently, nanoparticles were homogenously dispersed on $\mathrm{Fe}_{3} \mathrm{O}_{4}$ as a core with an average diameter of about $20 \mathrm{~nm}$. These analyses revealed that there is no roughness and aggregation present in the surface of $\mathrm{Fe}_{3} \mathrm{O}_{4} @ \mathrm{SiO}_{2} @ \mathrm{AMBI} / \mathrm{Cu}$.
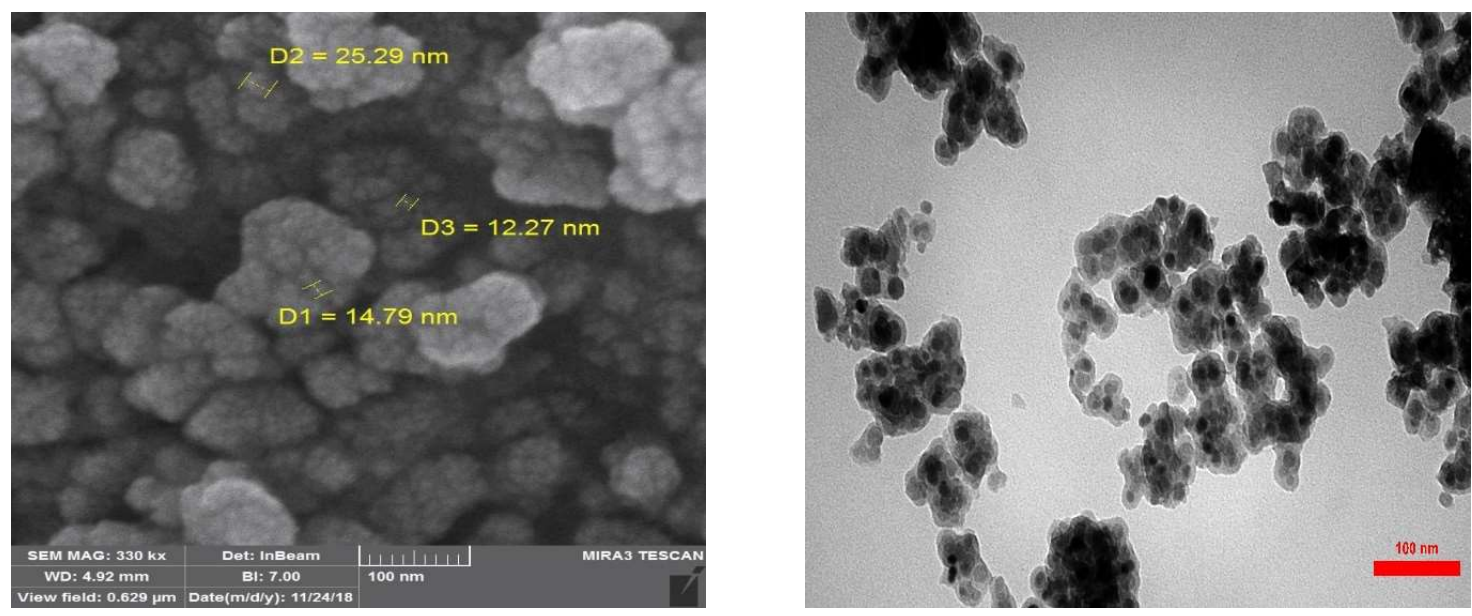

Fig. 2. SEM and TEM spectra of $\mathrm{Fe}_{3} \mathrm{O}_{4} @ \mathrm{SiO}_{2} @ \mathrm{AMBI} / \mathrm{Cu}$ 
The purity and crystalline structure of the synthesized $\mathrm{Fe}_{3} \mathrm{O}_{4} @ \mathrm{SiO}_{2} @ \mathrm{AMBI} / \mathrm{Cu}$ were studied using $\mathrm{X}$-ray diffractions. The XRD pattern of the powders of the final nanocatalyst is indicated in Figure 3. Corresponding peaks of $\mathrm{Fe}_{3} \mathrm{O}_{4}$ in XRD were observed at $2 \theta=30.0,35.0,42.0,52.0,56.0$, and 62.0, which are similar to the pattern of the reported $\mathrm{Fe}_{3} \mathrm{O}_{4}$ nanoparticles before. ${ }^{19,30}$

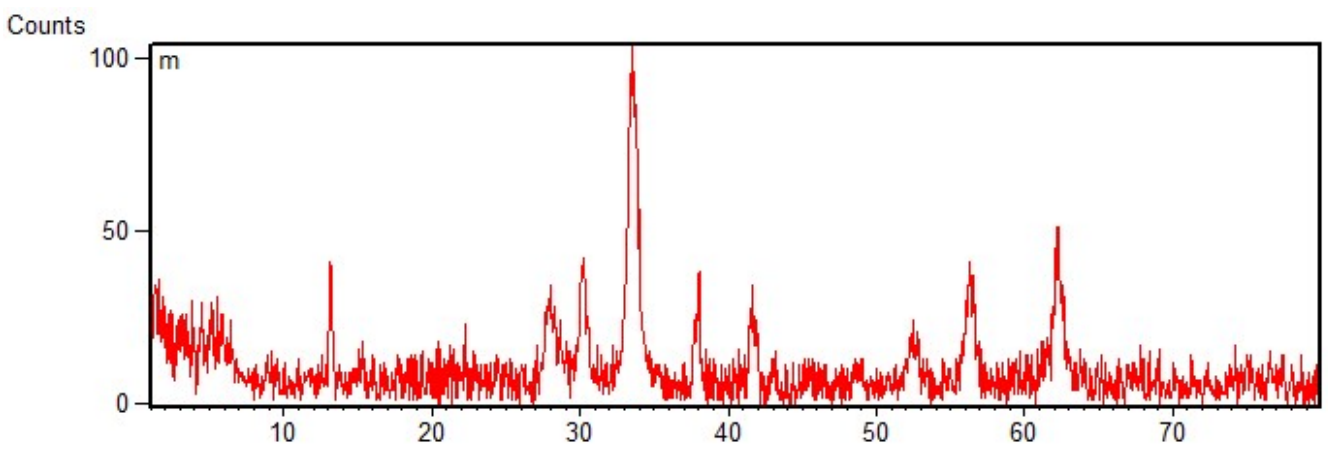

Fig. 3. XRD pattern of $\mathrm{Fe}_{3} \mathrm{O}_{4} @ \mathrm{SiO}_{2} @ \mathrm{AMBI} / \mathrm{Cu}$

EDX analysis was performed to study the elemental compositions of $\mathrm{Fe}_{3} \mathrm{O}_{4} @ \mathrm{SiO}_{2} @ \mathrm{AMBI} / \mathrm{Cu}$. The EDX spectrum of $\mathrm{Fe}_{3} \mathrm{O}_{4} @ \mathrm{SiO}_{2} @ \mathrm{AMBI} / \mathrm{Cu}$ is presented in Figure 4. In this spectrum, the existence of $\mathrm{Fe}$ and $\mathrm{O}$ has proved the synthesis of $\mathrm{Fe}_{3} \mathrm{O}_{4}$. In addition, EDX shows the presence of $\mathrm{Cu}, \mathrm{N}$, and $\mathrm{Si}$ which proved the successful synthesis of $\mathrm{Fe}_{3} \mathrm{O}_{4} @ \mathrm{SiO}_{2} @ \mathrm{AMBI} / \mathrm{Cu}$.

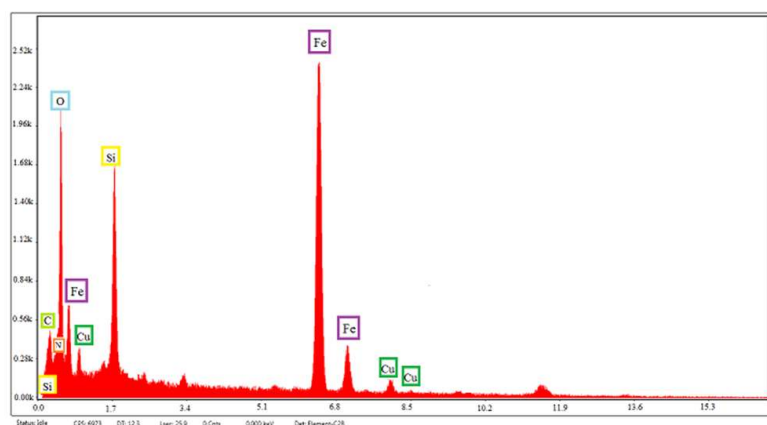

Fig. 4. EDX spectrum of $\mathrm{Fe}_{3} \mathrm{O}_{4} @ \mathrm{SiO}_{2} @ \mathrm{AMBI} / \mathrm{Cu}$

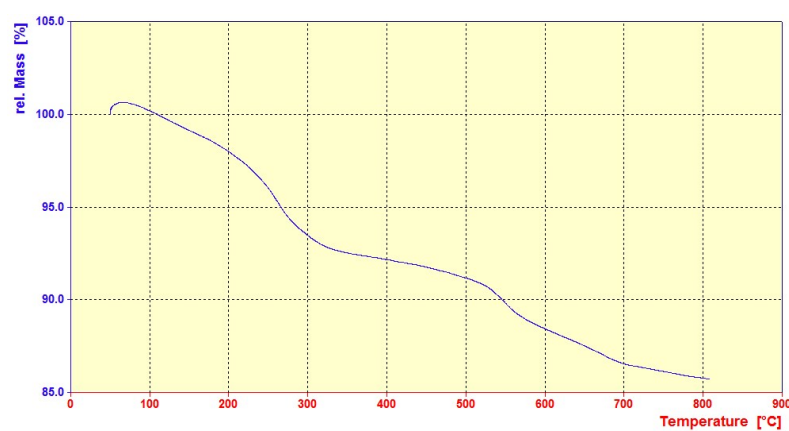

Fig. 5. TGA curve of $\mathrm{Fe}_{3} \mathrm{O}_{4} @ \mathrm{SiO}_{2} @ \mathrm{AMBI} / \mathrm{Cu}$

The TGA analysis of the synthesized $\mathrm{Fe}_{3} \mathrm{O}_{4} @ \mathrm{SiO}_{2} @ \mathrm{AMBI} / \mathrm{Cu}$ was taken to understand the stability of it (Figure 5). In TGA, the weight loss under $200^{\circ} \mathrm{C}$ is related to volatile compounds and the weight loss at about $500^{\circ} \mathrm{C}$ is related to decomposition of ligand. Furthermore, due to the existence of $\mathrm{Cu}$ and $\mathrm{Fe}_{3} \mathrm{O}_{4}$, it did not decompose completely at temperatures above $800^{\circ} \mathrm{C}$.

\subsection{Catalytic activity of $\mathrm{Fe}_{3} \mathrm{O}_{4} @ \mathrm{SiO}_{2} @ \mathrm{AMBI} / \mathrm{Cu}$ nanocatalyst}

Most of the click reactions which started with aryl iodide need long reaction times and hard conditions. Therefore, we decided to develop this kind of reactions with a new and efficient protocol to proceed this reaction under mild conditions. Initial studies including the optimization of the type of the catalyst, the amount of the catalyst, the reaction time, the reaction temperature, and the type of the base and the solvent were conducted using iodobenzene, phenyl acetylene and sodium azide as the model reaction.

First of all, to understand the best catalyst, various catalysts including $\mathrm{CuCl}, \mathrm{CuI}, \mathrm{Cu}_{2} \mathrm{O}$, and $\mathrm{Fe}_{3} \mathrm{O}_{4} @ \mathrm{SiO}_{2} @ \mathrm{AMBI} / \mathrm{Cu}$ were used. In comparison to other catalytic systems, the best yield was gained using the $\mathrm{Fe}_{3} \mathrm{O}_{4} @ \mathrm{SiO}_{2} @ \mathrm{AMBI} / \mathrm{Cu}$ nanocatalyst. In the next step, in order to optimize the amount of the catalyst, three different amounts of catalysts, including 10, 20, and $30 \mathrm{mg}$ of $\mathrm{Fe}_{3} \mathrm{O}_{4} @ \mathrm{SiO}_{2} @ \mathrm{AMBI} / \mathrm{Cu}$ catalyst were used, in which by using $30 \mathrm{mg}$ of catalyst, 96\% yield was obtained. For the acquisition of the best temperature of the reaction, after carrying out the reaction in 
different temperatures, it was concluded that the optimizied temperature is $100^{\circ} \mathrm{C}$. Afterwards, different ligands were used (L-proline, picolinic acid, DMEDA, phenantroline, and bipyridine) to carry out coupling reactions of aryl iodide. From the results, it could be concluded that in the presence of Lproline, higher yield of the product was gained. In order to select the best base, $\mathrm{NaOH}, \mathrm{K}_{2} \mathrm{CO}_{3}, \mathrm{Cs}_{2} \mathrm{CO}_{3}$, $\mathrm{NaHCO}_{3}$, and $\mathrm{K}_{2} \mathrm{PO}_{4}$ were used and as the result, in the presence of $\mathrm{NaOH}$, the best result was gained. Finally, for the selection of the best solvent, the performance of several solvents was evaluated. In comparison to toluene, dioxane, and $\mathrm{EtOH}$ as a solvent, using the combination of $\mathrm{H}_{2} \mathrm{O}$ /DMSO yielded to the best results for this reaction (Table 1). By this optimized condition, various derivatives were synthesized (Scheme 2).

Table 1. Optimizing different parameters in the model reaction

\begin{tabular}{|c|c|c|c|c|c|c|c|c|}
\hline Enter & Catalyst & $\begin{array}{l}\text { Cat } \\
{[\%]}\end{array}$ & Ligand & Base & $\mathrm{T}\left({ }^{\circ} \mathrm{C}\right)$ & Time(h) & Solvent & Yield $[\%]^{[\mathrm{a}]}$ \\
\hline 1 & - & - & L-proline & $\mathrm{NaOH}$ & 100 & 12 & $\mathrm{DMSO} / \mathrm{H}_{2} \mathrm{O}$ & trace \\
\hline 2 & $\mathrm{CuCl}$ & 20 & L-proline & $\mathrm{NaOH}$ & 100 & 12 & $\mathrm{DMSO} / \mathrm{H}_{2} \mathrm{O}$ & 45 \\
\hline 3 & $\mathrm{CuI}$ & 20 & L-proline & $\mathrm{NaOH}$ & 100 & 12 & $\mathrm{DMSO} / \mathrm{H}_{2} \mathrm{O}$ & 50 \\
\hline 4 & $\mathrm{Cu}_{2} \mathrm{O}$ & 20 & L-proline & $\mathrm{NaOH}$ & 100 & 12 & $\mathrm{DMSO} / \mathrm{H}_{2} \mathrm{O}$ & 40 \\
\hline 5 & $\mathrm{Fe}_{3} \mathrm{O}_{4} @ \mathrm{SiO}_{2} @ \mathrm{AMBI} / \mathrm{Cu}$ & 10 & L-proline & $\mathrm{NaOH}$ & 100 & 2 & $\mathrm{DMSO} / \mathrm{H}_{2} \mathrm{O}$ & 73 \\
\hline 6 & $\mathrm{Fe}_{3} \mathrm{O}_{4} @ \mathrm{SiO}_{2} @ \mathrm{AMBI} / \mathrm{Cu}$ & 20 & L-proline & $\mathrm{NaOH}$ & 100 & 2 & $\mathrm{DMSO} / \mathrm{H}_{2} \mathrm{O}$ & 84 \\
\hline 7 & $\mathrm{Fe}_{3} \mathrm{O}_{4} @ \mathrm{SiO}_{2} @ \mathrm{AMBI} / \mathrm{Cu}$ & 30 & L-proline & $\mathrm{NaOH}$ & 100 & 2 & $\mathrm{DMSO} / \mathrm{H}_{2} \mathrm{O}$ & 96 \\
\hline 8 & $\mathrm{Fe}_{3} \mathrm{O}_{4} @ \mathrm{SiO}_{2} @ \mathrm{AMBI} / \mathrm{Cu}$ & 30 & picolinic acid & $\mathrm{NaOH}$ & 100 & 12 & $\mathrm{DMSO} / \mathrm{H}_{2} \mathrm{O}$ & trace \\
\hline 9 & $\mathrm{Fe}_{3} \mathrm{O}_{4} @ \mathrm{SiO}_{2} @ \mathrm{AMBI} / \mathrm{Cu}$ & 30 & DMEDA & $\mathrm{NaOH}$ & 100 & 12 & $\mathrm{DMSO} / \mathrm{H}_{2} \mathrm{O}$ & trace \\
\hline 10 & $\mathrm{Fe}_{3} \mathrm{O}_{4} @ \mathrm{SiO}_{2} @ \mathrm{AMBI} / \mathrm{Cu}$ & 30 & 2,2'-bipyridine & $\mathrm{NaOH}$ & 100 & 12 & $\mathrm{DMSO} / \mathrm{H}_{2} \mathrm{O}$ & trace \\
\hline 11 & $\mathrm{Fe}_{3} \mathrm{O}_{4} @ \mathrm{SiO}_{2} @ \mathrm{AMBI} / \mathrm{Cu}$ & 30 & 1,10-phenanthroline & $\mathrm{NaOH}$ & 100 & 12 & $\mathrm{DMSO} / \mathrm{H}_{2} \mathrm{O}$ & trace \\
\hline 12 & $\mathrm{Fe}_{3} \mathrm{O}_{4} @ \mathrm{SiO}_{2} @ \mathrm{AMBI} / \mathrm{Cu}$ & 30 & L-proline & $\mathrm{K}_{2} \mathrm{CO}_{3}$ & 100 & 8 & $\mathrm{DMSO} / \mathrm{H}_{2} \mathrm{O}$ & 53 \\
\hline 13 & $\mathrm{Fe}_{3} \mathrm{O}_{4} @ \mathrm{SiO}_{2} @ \mathrm{AMBI} / \mathrm{Cu}$ & 30 & L-proline & $\mathrm{Cs}_{2} \mathrm{CO}_{3}$ & 100 & 8 & $\mathrm{DMSO} / \mathrm{H}_{2} \mathrm{O}$ & 63 \\
\hline 14 & $\mathrm{Fe}_{3} \mathrm{O}_{4} @ \mathrm{SiO}_{2} @ \mathrm{AMBI} / \mathrm{Cu}$ & 30 & L-proline & $\mathrm{NaHCO}_{3}$ & 100 & 8 & $\mathrm{DMSO} / \mathrm{H}_{2} \mathrm{O}$ & 54 \\
\hline 15 & $\mathrm{Fe}_{3} \mathrm{O}_{4} @ \mathrm{SiO}_{2} @ \mathrm{AMBI} / \mathrm{Cu}$ & 30 & L-proline & $\mathrm{K}_{2} \mathrm{PO}_{4}$ & 100 & 8 & $\mathrm{DMSO} / \mathrm{H}_{2} \mathrm{O}$ & 40 \\
\hline 16 & $\mathrm{Fe}_{3} \mathrm{O}_{4} @ \mathrm{SiO}_{2} @ \mathrm{AMBI} / \mathrm{Cu}$ & 30 & L-proline & $\mathrm{NaOH}$ & 100 & 8 & DMSO & 71 \\
\hline 17 & $\mathrm{Fe}_{3} \mathrm{O}_{4} @ \mathrm{SiO}_{2} @ \mathrm{AMBI} / \mathrm{Cu}$ & 30 & L-proline & $\mathrm{NaOH}$ & 90 & 8 & $\mathrm{H}_{2} \mathrm{O}$ & 77 \\
\hline 18 & $\mathrm{Fe}_{3} \mathrm{O}_{4} @ \mathrm{SiO}_{2} @ \mathrm{AMBI} / \mathrm{Cu}$ & 30 & L-proline & $\mathrm{NaOH}$ & 90 & 8 & Toluene & 23 \\
\hline 19 & $\mathrm{Fe}_{3} \mathrm{O}_{4} @ \mathrm{SiO}_{2} @ \mathrm{AMBI} / \mathrm{Cu}$ & 30 & L-proline & $\mathrm{NaOH}$ & 90 & 8 & Dioxane & 32 \\
\hline 20 & $\mathrm{Fe}_{3} \mathrm{O}_{4} @ \mathrm{SiO}_{2} @ \mathrm{AMBI} / \mathrm{Cu}$ & 30 & L-proline & $\mathrm{NaOH}$ & 80 & 8 & $\mathrm{EtOH}$ & 61 \\
\hline 21 & $\mathrm{Fe}_{3} \mathrm{O}_{4} @ \mathrm{SiO}_{2} @ \mathrm{AMBI} / \mathrm{Cu}$ & 30 & L-proline & $\mathrm{NaOH}$ & r.t & 4 & $\mathrm{DMSO} / \mathrm{H}_{2} \mathrm{O}$ & 63 \\
\hline
\end{tabular}

Isolated yield

Almost all of the abovementioned optimizing reactions were studied in the reaction of benzyl bromide, phenyl acetylene, and sodium azide as the model reaction.. In this case, the best result was gained using $\mathrm{H}_{2} \mathrm{O}$ as the solvent and at $90^{\circ} \mathrm{C}$ (entry 5, Table 2). Also, different derivatives 1,4-disubstituted 1,2,3triazoles using benzyl bromide/chloride, aryl alkyne and sodium azide were synthesized by this condition (Scheme 3).

Table 2. Optimizing different parameters in the click reaction of benzyl bromide and phenyl acetylene $^{\mathrm{a}}$

\begin{tabular}{|c|c|c|c|c|c|c|}
\hline Enter & Catalyst & Cat $[\%]$ & $\mathrm{T}\left({ }^{\circ} \mathrm{C}\right)$ & Time(h) & Solvent & Yield $[\%]^{[a]}$ \\
\hline 1 & - & - & 50 & 7 & $\mathrm{H}_{2} \mathrm{O}$ & - \\
\hline 2 & - & - & 90 & 8 & $\mathrm{H}_{2} \mathrm{O}$ & 21 \\
\hline 3 & $\mathrm{Fe}_{3} \mathrm{O}_{4} @ \mathrm{SiO}_{2} @ \mathrm{AMBI} / \mathrm{Cu}$ & 10 & 90 & 8 & $\mathrm{H}_{2} \mathrm{O}$ & 76 \\
\hline 4 & $\mathrm{Fe}_{3} \mathrm{O}_{4} @ \mathrm{SiO}_{2} @ \mathrm{AMBI} / \mathrm{Cu}$ & 20 & 90 & 8 & $\mathrm{H}_{2} \mathrm{O}$ & 87 \\
\hline 5 & $\mathrm{Fe}_{3} \mathrm{O}_{4} @ \mathrm{SiO}_{2} @ \mathrm{AMBI} / \mathrm{Cu}$ & 30 & 90 & 0.4 & $\mathrm{H}_{2} \mathrm{O}$ & 98 \\
\hline 6 & $\mathrm{Fe}_{3} \mathrm{O}_{4} @ \mathrm{SiO}_{2} @ \mathrm{AMBI} / \mathrm{Cu}$ & 40 & 90 & 0.4 & $\mathrm{H}_{2} \mathrm{O}$ & 98 \\
\hline 7 & $\mathrm{Fe}_{3} \mathrm{O}_{4} @ \mathrm{SiO}_{2} @ \mathrm{AMBI} / \mathrm{Cu}$ & 30 & r.t & 1 & $\mathrm{H}_{2} \mathrm{O}$ & 51 \\
\hline 8 & $\mathrm{Fe}_{3} \mathrm{O}_{4} @ \mathrm{SiO}_{2} @ \mathrm{AMBI} / \mathrm{Cu}$ & 30 & r.t & 8 & $\mathrm{H}_{2} \mathrm{O}$ & 81 \\
\hline 9 & $\mathrm{Fe}_{3} \mathrm{O}_{4} @ \mathrm{SiO}_{2} @ \mathrm{AMBI} / \mathrm{Cu}$ & 30 & 90 & 2 & Toluene & 15 \\
\hline 10 & $\mathrm{Fe}_{3} \mathrm{O}_{4} @ \mathrm{SiO}_{2} @ \mathrm{AMBI} / \mathrm{Cu}$ & 30 & Reflux & 2 & $\mathrm{CH}_{3} \mathrm{OH}$ & 65 \\
\hline 11 & $\mathrm{Fe}_{3} \mathrm{O}_{4} @ \mathrm{SiO}_{2} @ \mathrm{AMBI} / \mathrm{Cu}$ & 30 & Reflux & 2 & $\mathrm{CH}_{3} \mathrm{CN}$ & 38 \\
\hline 12 & $\mathrm{Fe}_{3} \mathrm{O}_{4} @ \mathrm{SiO}_{2} @ \mathrm{AMBI} / \mathrm{Cu}$ & 30 & Reflux & 1 & $\mathrm{EtOH} / \mathrm{H}_{2} \mathrm{O}$ & 83 \\
\hline 13 & $\mathrm{Cu} / \mathrm{SiO}_{2}$ & 30 & Reflux & 12 & $\mathrm{H}_{2} \mathrm{O}$ & 95 \\
\hline 14 & Chitosan-coated $\mathrm{Fe}_{3} \mathrm{O}_{4} / \mathrm{Cu}$ & 30 & Reflux & 12 & $\mathrm{CH}_{2} \mathrm{Cl}_{2}$ & 94 \\
\hline 15 & Chitosan/Cu & 30 & 90 & 4 & $\mathrm{H}_{2} \mathrm{O}$ & 98 \\
\hline
\end{tabular}




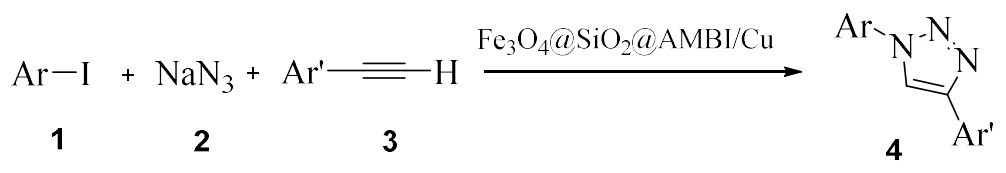<smiles>c1ccc(-c2cn(-c3ccccc3)nn2)cc1</smiles>

$4 a, 96 \%, 2 h$<smiles>Cc1ccc(-n2cc(-c3ccccc3)nn2)cc1</smiles>

4d, $92 \%, 2 h$<smiles>Cc1ccc(-n2cc(-c3ccccc3)nn2)cc1[N+](=O)[O-]</smiles>

$4 g, 88 \%, 2 h$<smiles>Cc1ccc(-c2cn(-c3ccccc3)nn2)cc1</smiles>

$4 b, 94 \%, 2 h$<smiles>Cc1ccccc1-n1cc(-c2ccccc2)nn1</smiles>

$4 e, 90 \%, 2 h$<smiles>Cc1ccc(-n2cc(-c3ccccc3)nn2)cc1C</smiles>

$4 i, 85 \%, 2 h$<smiles>Clc1ccc(-n2cc(-c3ccccc3)nn2)cc1</smiles>

$4 c, 94 \%, 2 h$<smiles>Clc1ccccc1-n1cc(-c2ccccc2)nn1</smiles>

4f, $93 \%, 2 h$<smiles>Clc1cccc(-n2cc(-c3ccccc3)nn2)c1</smiles>

4j, 93\%, $2 h$<smiles>O=[N+]([O-])c1ccc(-n2cc(-c3ccccc3)nn2)cc1</smiles>

$4 k, 89 \%, 2 h$

Scheme 2. Substrate scope of 1,4-disubstituted-1,2,3-triazoles using aryl iodide. Optimized reaction conditions: Aryl iodide (1 mmol), aryl alkyne $(1 \mathrm{mmol})$, sodium azide $(1.2 \mathrm{mmol})$, sodium ascorbate (30 mol \%), 20 mol \% of $\mathrm{Fe}_{3} \mathrm{O}_{4} @ \mathrm{SiO}_{2} @ \mathrm{AMBI} / \mathrm{Cu}, \mathrm{DMSO} / \mathrm{H}_{2} \mathrm{O}, 100{ }^{\circ} \mathrm{C}$. 
<smiles>c1ccc(Cn2cc(-c3ccccc3)nn2)cc1</smiles>

$6 a, 98 \%, 15$ min<smiles>c1ccc(Cn2cc(Oc3ccccc3)nn2)cc1</smiles>

6d, $93 \%, 15 \mathrm{~min}$
$\mathrm{Fe}_{3} \mathrm{O}_{4} @ \mathrm{SiO}_{2} @ \mathrm{AMBI} / \mathrm{Cu}$

3<smiles></smiles><smiles>CC(O)(c1ccccc1)c1cn(Cc2ccccc2)nn1</smiles>

6b, $90 \%, 20 \mathrm{~min}$<smiles>Cc1ccc(-c2cn(Cc3ccccc3)nn2)cc1</smiles>

$6 c, 94 \%, 15 \min$<smiles>Cc1ccc(-c2cn(Cc3ccc([N+](=O)[O-])cc3)nn2)cc1</smiles>
$6 \mathrm{~g}, 93 \%, 15 \mathrm{~min}$<smiles>O=C(Cn1cc(-c2ccccc2)nn1)c1ccccc1</smiles>

$6 i, 92 \%, 25$ min<smiles>c1ccc(Cn2cc(-c3ccccc3)nn2)cc1</smiles>

6f, $97 \%, 25 \mathrm{~min}$<smiles>COc1ccc(Cn2cc(-c3ccccc3)nn2)cc1</smiles>

6k, 92\%, 15 min<smiles>O=C(Cn1cc(-c2ccccc2)nn1)c1ccc(Br)cc1</smiles>

$6 \mathrm{k}, 90 \%, 30 \mathrm{~min}$

Scheme 3. Substrate scope of 1,4-disubstituted 1,2,3-triazoles using benzyl halide. Optimized reaction conditions: Benzyl bromide (5a-5e, 6g-6k) /benzyl chloride (5f) (1 mmol), aryl alkyne (1 mmol), sodium azide $(1.2 \mathrm{mmol})$, sodium ascorbate $(30 \mathrm{~mol} \%), 20 \mathrm{~mol} \%$ of $\mathrm{Fe}_{3} \mathrm{O}_{4} @ \mathrm{SiO}_{2} @ \mathrm{AMBI} / \mathrm{Cu}, \mathrm{H}_{2} \mathrm{O}, 80{ }^{\circ} \mathrm{C}$.

\subsection{Mechanism}

In the suggested mechanism using $\mathrm{Fe}_{3} \mathrm{O}_{4} @ \mathrm{SiO}_{2} @ \mathrm{AMBI} / \mathrm{Cu}$ nanocatalyst in Scheme 4. initially, $\mathrm{Cu}$ reacted with sodium azide to form $\mathrm{Cu}$-azide intermediate. Afterwards, by the addition of aryl iodide/benzyl halide, aryl/benzyl azide $\mathbf{B}$ was obtained. Then, by the activation of alkyne using $\mathrm{Cu}$ catalyst, $\mathrm{Cu}$-alkyne intermediate $\mathbf{A}$ was formed and by the addition of aryl/benzyl azide, Cu-triazole intermediate $\mathbf{C}$ was shaped, which led to the final substitution of triazole $\mathbf{D}$ (Scheme 4). ${ }^{19}$ 


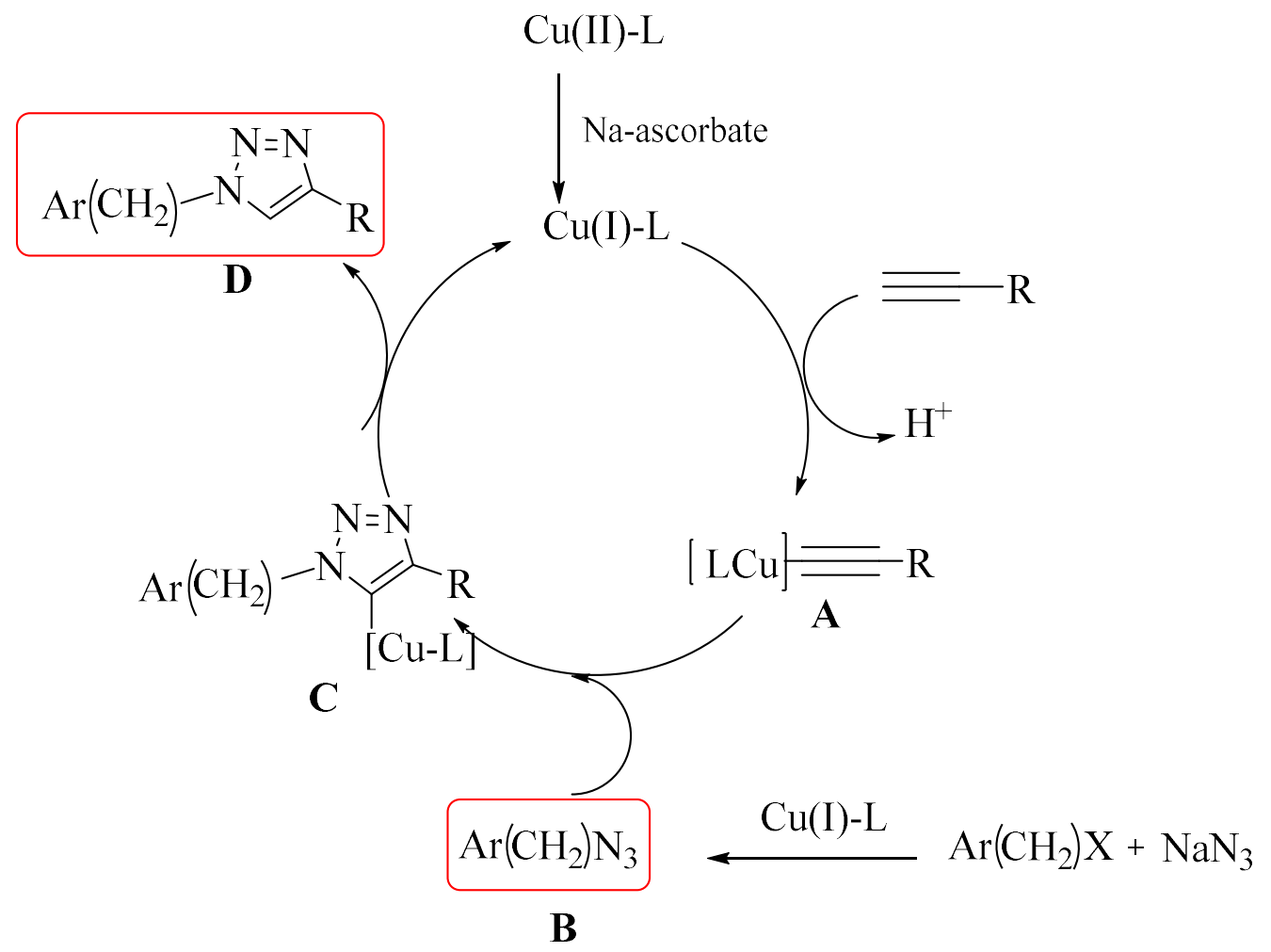

Scheme 4. Proposed mechanism for the synthesis of substituted triazoles

\subsection{Reusability of $\mathrm{Fe}_{3} \mathrm{O}_{4} @ \mathrm{SiO}_{2} @ \mathrm{AMBI} / \mathrm{Cu}$ nanocatalyst}

The stability of $\mathrm{Fe}_{3} \mathrm{O}_{4} @ \mathrm{SiO}_{2} @ \mathrm{AMBI} / \mathrm{Cu}$ nanocatalyst was studied by performing 6 different runs under the optimized reaction conditions. The $\mathrm{Fe}_{3} \mathrm{O}_{4} @ \mathrm{SiO}_{2} @ \mathrm{AMBI} / \mathrm{Cu}$ nanocatalyst could be easily separated by an external magnet from the reaction media before each upcoming run. The recyclability of the catalyst indicates that the yield of the click reaction using aryl iodide/benzyl halide was decreased slightly from $96 \%$ to $89 \%$ after 6 runs.

\section{Conclusion}

To sum up, $\mathrm{Fe}_{3} \mathrm{O}_{4} @ \mathrm{SiO}_{2} @ \mathrm{AMBI} / \mathrm{Cu}$ nanocatalyst is successfully synthesized and used in two different click reactions. Following developments of our work could be mentioned here: (1) Synthesis of $\mathrm{Fe}_{3} \mathrm{O}_{4} @ \mathrm{SiO}_{2} @ \mathrm{AMBI} / \mathrm{Cu}$ nanocatalyst could be simply achieved in the absence of expensive initial materials. (2) Click reaction using synthesized $\mathrm{Fe}_{3} \mathrm{O}_{4} @ \mathrm{SiO}_{2} @ \mathrm{AMBI} / \mathrm{Cu}$ was completed in lower time and milder reaction conditions compared to most of the reported works. (3) The synthesized nanocatalyst could be simply separated, recycled and used after completing the reaction.

\section{Acknowledgement}

The authors gratefully acknowledge the support from the Baqiyatallah University of Medical Sciences.

\section{Experimental}

\subsection{Materials and Methods}

All initial chemicals and materials were purchased from Merck and Aldrich. Also, characterizations were carried out using following instruments: a) FT-IR: Shimadzu FT-IR-8400S spectrophotometer, b) ${ }^{1} \mathrm{H}-\mathrm{NMR}$ : Bruker Avance $\left.500 \mathrm{MHz}, \mathrm{c}\right)$ SEM: KYKY- EM3200 at $26 \mathrm{KV}$, d) XRD: Jeoljdx-8030, e) TGA: Q50 V6.3 Build 189. 


\subsection{General procedure}

\subsection{1 $\mathrm{Fe}_{3} \mathrm{O}_{4} @ \mathrm{SiO}_{2} @ A M B I / C u$ nanocatalyst preparation}

$\mathrm{Fe}_{3} \mathrm{O}_{4}$ nanoparticles were synthesized using previous reported literatures. In brief, $5.838 \mathrm{~g}$ of $\mathrm{FeCl}_{3} .6 \mathrm{H}_{2} \mathrm{O}$ and $2.147 \mathrm{~g}$ of $\mathrm{FeCl}_{2} .4 \mathrm{H}_{2} \mathrm{O}$ were added to deionized water under $\mathrm{N}_{2}$ atmosphere at $85^{\circ} \mathrm{C}$. To this mixture, $10 \mathrm{ml}$ of $\mathrm{NH}_{4} \mathrm{OH}(25 \%)$ was added and stirred for $30 \mathrm{~min}$. After the completion of the reaction, produced nanoparticles were separated by an external magnet and dried in a vacuum oven at $60^{\circ} \mathrm{C}$. Next, for the synthesis of $\mathrm{Fe}_{3} \mathrm{O}_{4} @ \mathrm{SiO}_{2}, 0.5 \mathrm{~mL}$ of tetraethyl orthosilicate (TEOS) was added to the sonicated $\mathrm{Fe}_{3} \mathrm{O}_{4}$ in $20 \mathrm{~mL}$ of deionized water and $70 \mathrm{~mL}$ of EtOH and was stirred for $8 \mathrm{hrs}$. The resulted compound was separated by an external magnet, washed with water and $\mathrm{EtOH}$, and then dried in a vacuum oven at $60^{\circ} \mathrm{C}$. In the next step, $1 \mathrm{~g}$ of the synthesized $\mathrm{Fe}_{3} \mathrm{O}_{4} @ \mathrm{SiO}_{2}$ was added to Ball-Mill and $0.3 \mathrm{~g}$ of 2-(aminomethyl)benzimidazole dihydrochloride (98\%) (AMBI) plus $0.6 \mathrm{~g}$ of $\mathrm{K}_{2} \mathrm{CO}_{3}$ were added. The mixture was milled for $45 \mathrm{~min}$ at $30 \mathrm{~Hz}$. The resulted product was separated by an external magnet and washed 5 times with water and $\mathrm{EtOH}$ and then dried in a vacuum oven at $60^{\circ} \mathrm{C}$. This resulted product was dispersed in EtOH. Afterwards, $0.3 \mathrm{~g}$ of $\mathrm{Cu}(\mathrm{OAc}) 2$ was added to it and the mixture was refluxed at $80^{\circ} \mathrm{C}$ for $24 \mathrm{hrs}$. Finally, the final product was separated, washed, and dried in an oven.

\subsubsection{Click Reaction using aryl iodide}

The reaction was carried out using $1 \mathrm{mmol}$ of aryl iodide, $1 \mathrm{mmol}$ of aryl alkyne, $1.2 \mathrm{mmol}$ of sodium azide, 30mol \% of sodium ascorbate, and $20 \mathrm{~mol} \%$ of $\mathrm{Fe}_{3} \mathrm{O}_{4} @ \mathrm{SiO}_{2} @ \mathrm{AMBI} / \mathrm{Cu}$ nanocatalyst in $\mathrm{DMSO} / \mathrm{H}_{2} \mathrm{O}$. This combination was stirred for $2 \mathrm{hrs}$ at $100^{\circ} \mathrm{C}$ and the completion of the reaction was followed by thin layer chromatography (TLC). Resulted precipitation was separated and dried in room temperature.

\subsubsection{Click reaction using benzyl halide}

The reaction was carried out using $1 \mathrm{mmol}$ of benzyl bromide/chloride, 1mmol of aryl alkyne, $1.2 \mathrm{mmol}$ of sodium azide, 30mol \% of sodium ascorbate, and 20mol \% of $\mathrm{Fe}_{3} \mathrm{O}_{4} @ \mathrm{SiO}_{2} @ \mathrm{AMBI} / \mathrm{Cu}$ nanocatalyst in $\mathrm{H}_{2} \mathrm{O}$. This combination was stirred for $15 \mathrm{~min} \mathrm{~h}$ at $80^{\circ} \mathrm{C}$ and the completion of the reaction was followed by thin layer chromatography (TLC). Resulted precipitation was separated and dried in room temperature.

\subsection{Physical and Spectral Data} file.

The physical and spectral data of some of the products can be found in the supporting information

\section{References}

1.Sletten, E. M., \& Bertozzi, C. R. (2009). Bioorthogonal chemistry: fishing for selectivity in a sea of functionality. Angew. Chem. Int. Ed. En, 48(38), 6974-6998.

2.Wu, P., Feldman, A. K., Nugent, A. K., Hawker, C. J., Scheel, A., Voit B., \& Fokin, V. V. (2004). Efficiency and fidelity in a click-chemistry route to triazole dendrimers by the copper (I)-catalyzed ligation of azides and alkynes. Angew. Chem. Int. Ed. En, 43(30), 3928-3932.

3.a)Wu, P., Malkoch, M., Hunt, J. N., Vestberg, R., Kaltgrad, E., Finn, M. G., \& Hawker, C. J. (2005). Multivalent, bifunctional dendrimers prepared by click chemistry. Chem. Commun., (46), 57755777.b) Rostovtsev, V. V., Green, L. G., Fokin, V. V., \& Sharpless, K. B. (2002). A stepwise huisgen cycloaddition process: copper (I)-catalyzed regioselective "ligation" of azides and terminal alkynes. Angew. Chem. Int. Ed. En, 41(14), 2596-2599.

4. Moses, J. E., \& Moorhouse, A. D. (2007). The growing applications of click chemistry. Chem. Soc. Rev., 36(8), 1249-1262.

5. Kolb, H. C., \& Sharpless, K. B. (2003). The growing impact of click chemistry on drug discovery. Drug Discov. Today, 8(24), 1128-1137. 
6. Appukkuttan, P., Dehaen, W., Fokin, V. V., \& Van der Eycken, E. (2004). A microwave-assisted click chemistry synthesis of 1,4-disubstituted 1,2,3-triazoles via a copper (I)-catalyzed threecomponent reaction. Org. Lett., 6(23), 4223-4225.

7. Nandivada, H., Jiang, X., \& Lahann, J. (2007). Click chemistry: versatility and control in the hands of materials scientists. Adv. Mater., 19(17), 2197-2208.

8. Bouillon, C., Meyer, A., Vidal, S., Jochum, A., Chevolot, Y., Cloarec, J. P., ... \& Morvan, F. (2006). Microwave assisted "click" chemistry for the synthesis of multiple labeled-carbohydrate oligonucleotides on solid support. The J. Org. Chem., 71(12), 4700-4702.

9. Finn, M. G., \& Fokin, V. V. (2010). Click chemistry: function follows form. Chem. Soc. Rev., 39(4), 1231-1232.

10. Tron, G. C., Pirali, T., Billington, R. A., Canonico, P. L., Sorba, G., \& Genazzani, A. A. (2008). Click chemistry reactions in medicinal chemistry: Applications of the 1, 3-dipolar cycloaddition between azides and alkynes. Med. Res. Rev., 28(2), 278-308.

11. Ertl, G., Knözinger, H., \& Weitkamp, J. (Eds.). (2008). Preparation of solid catalysts. John Wiley \& Sons.

12. Boudart, M. (1985). Heterogeneous catalysis by metals. J.Mol. Catal., 30(1-2), 27-38.

13. Boudart, M. (1969). Catalysis by supported metals. In Advances in catalysis (Vol. 20, pp. 153-166). Academic Press.

14. Wan, W., Ammal, S. C., Lin, Z., You, K. E., Heyden, A., \& Chen, J. G. (2018). Controlling reaction pathways of selective C-O bond cleavage of glycerol. Nat. Commun., 9(1), 4612.

15. Lum, Y., \& Ager, J. W. (2019). Evidence for product-specific active sites on oxide-derived $\mathrm{Cu}$ catalysts for electrochemical CO 2 reduction. Nat. Catal., 2(1), 86.

16. Marberger, A., Petrov, A. W., Steiger, P., Elsener, M., Kröcher, O., Nachtegaal, M., \& Ferri, D. (2018). Time-resolved copper speciation during selective catalytic reduction of $\mathrm{NO}$ on $\mathrm{Cu}-\mathrm{SSZ}-13$. Nat. Catal., 1(3), 221.

17. Marcinkowski, M. D., Darby, M. T., Liu, J., Wimble, J. M., Lucci, F. R., Lee, S., ... \& Sykes, E. C. H. (2018). $\mathrm{Pt} / \mathrm{Cu}$ single-atom alloys as coke-resistant catalysts for efficient $\mathrm{C}-\mathrm{H}$ activation. Nat. Chem., 10(3), 325.

18. Liu, L., \& Corma, A. (2018). Metal catalysts for heterogeneous catalysis: from single atoms to nanoclusters and nanoparticles. Chem. Rev., 118(10), 4981-5079.

19. Tourani, H., Naimi-Jamal, M. Reza., Panahi, L., Dekamin, M. G. (2019). Nanoporous metal-organic framework $\mathrm{Cu}_{2}(\mathrm{BDC})_{2}(\mathrm{DABCO})$ as an efficient heterogeneous catalyst for one-pot facile synthesis of 1,2,3-triazole derivatives in ethanol and evaluating antimicrobial activity of the novel derivatives. Sci. Iran. DOI:10.24200/SCI.2018.50731.1841

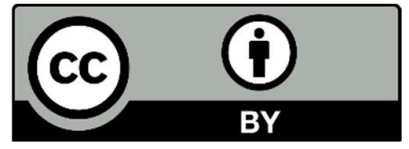

(C) 2020 by the authors; licensee Growing Science, Canada. This is an open access article distributed under the terms and conditions of the Creative Commons Attribution (CC-BY) license (http://creativecommons.org/licenses/by/4.0/). 